\title{
The Hague International Court of Law and Israel The Jewish Settlements A Reflection to the Nearest Past
}

\author{
Avi Bitzur ${ }^{1}$ \\ ${ }^{1}$ Home Front Defense and Security Program, Beit Berl Academic College, Israel \\ Correspondence: Avi Bitzur is head of the Home Front Defense and Security Program, Beit Berl Academic College, \\ Israel.
}

Received: April 5, 2021

doi:10.11114/ijsss.v9i3.5206
Accepted: April 12, $2021 \quad$ Available online: April 13, 2021

URL: https://doi.org/10.11114/ijsss.v9i3.5206

\begin{abstract}
One of the major problems that the hague international court of law is trying to deal with is the question about the legality of the jewish settelments at the west bank of the Jorden river-one of the outcomes from the 1967 war. Throughout history, the treatment of non-combatant civilian populations has been examined from various angles, most prominently with respect to the issue of the displacement of those on the losing side of a conflict, while the victorious party often settles the seized land with "less desirable" elements within its own population. ${ }^{1}$

This phenomenon is repeated in the exile of the Jewish people throughout history; the exile of criminals from England to Australia between 1788 and 1868; and in the appalling efforts of ethnic cleansing pursued by the Nazis in the Second World War, the Soviet Union's purge in Eastern Europe the 1950s, or the French rule of Algeria. ${ }^{2}$

This has been the case in countless wars and conflicts worldwide, one of the most prominent of which is the Israeli-Palestinian conflict. Here, the issue at heart is Jewish settlement in an area the Palestinians call the "West Bank" of the Jordan River and that Jews refer to as "Judea and Samaria" and see as an inextricable part of their ancestral homeland, of which they had been robbed and which they liberated.
\end{abstract}

On November 18, 2019, US Secretary of State Mike Pompeo announced an announcement that in this article I wish to examen as a reflection to the major problem that the hague court of law call that this is "a crime of war" and Israel call it "our legal right"-who is on the right side?

At first glance, this statement seems to contradict everything that has been said, done statement? Or is it that the concept of "illegal settlements" is a distortion of the Geneva Convention? ${ }^{3}$

The first chapter of this essay focuses on international law and whether it is a doctrine set in stone or a mutable fabric of woven conventions, including some that may be politically motivated or biased with respect to a certain issue, namely, populating disputed areas with the people of a party perceived as an occupying force.

The second chapter of this essay focuses on the dispute over the settlement enterprise in the Israeli-Palestinian case and how it is viewed from a number of completely different perspectives.

The third chapter of this essay focuses on the circumstances and motives that drove the latest American administration to make such a controversial statement.the big question is are these circumstances still valid under a new American regime? how such statement affects the Hauge court decisions about investigate the so called war crimes made in Israel? The final chapter of this essay will summarize and attempt to predict the future results of this move: Whether Israel -

\footnotetext{
${ }^{1}$ Morgenthau, H. J. (1948). Politics Among Nations: The Struggle for Power and Peace, New York, Alfred A. Knopf, p.50

${ }^{2}$ Barclay, F (2017). "Settler colonialism and French Algeria" in Settler Colonial Studies, Vol. 8, no.2, pp.115-130

${ }^{3}$ Baker, Alan (2019). "The Legality of Israel's Settlements: Flaws in the Carter-Era Hansell Memorandum," Jerusalem Center for Public Affairs
} 
as the Palestinians have already warned ${ }^{4}$ - plans to exploit the court move in favor of annexing areas it perceives as a bulwark against threats to its sovereignty, such as the Jordan Valley; or whether this move will brace the parties' ability to, for example, explore a land swap, and will this render the two-state solution ${ }^{5}$ upon which the Israeli-Palestinian peace process has been so far based invalid.

This paper will try to outline the possibilities this decision of the court may herald, and delve into its implications, reasoning, and potential consequences. On this days that we make the scope on the Hague court to check Israel crime of war this essay will try to open another scope to events that occurred only three years ago.

Keywords: Israel, settekments, Palestinians, Pompeo'Hauge court, peace agremment

\section{International Law - The Fourth Geneva Convention}

The international court of law that is sitting in Hauge at the Netherlands decided that Israel made war crimes during military operations at the Gaza strip and in the decisions all around the years in the establishment of the Jewish settlements at Judea and Samaria. According to the court the events are crimes against the international law.If we put aside the military operations we surely understand that the settelments are the major problem and I will try to explain why.

When the Second World War ended, over 40 peoples worldwide found themselves displaced, homeless, and vulnerable to various kinds of threats. ${ }^{6}$ This unprecedented, staggering number included Germans, Soviets, and Hungarian civilians, as well as people in East Asia (the battleground with Japan) and Africa (the battleground with Italy), ${ }^{7}$ and prompted a need for the immediate drafting of international rules and norms in order to protect civilians facing these circumstances.

In 1949, the Fourth Geneva Convention, which deals with this issue, was drafted. It focuses on, among other things, attempts by the victorious power to forcibly displace the defeated party's civilians from occupied territories and settle the occupier's civilians in their place.

To that end, Article 49 of the Fourth Geneva Convention states: "The Occupying Power shall not deport or transfer parts of its own civilian population into the territory it occupies." ${ }^{8}$

To illustrate the decision, Baker, for example, cites the interpretation provided by the International Committee of the Red Cross itself in 1958, which states: "This clause [...] intended to prevent a practice adopted during the Second World War by certain Powers, which transferred portions of their own population to occupied territory for political and racial reasons or in order, as they claimed, to colonize those territories. Such transfers worsened the economic situation of the native population and endangered their separate existence as a race." ${ }^{19}$

That is to say, this interpretation regards civilian settlement in occupied territory as a forceful act involving the exile, displacement, deportation, or evacuation of the area's original residents - not a voluntary act of settlement.

But Baker is but one voice, and in contrast, countless others argue that Article 49 of the Fourth Geneva Convention, which begins by stating, "The individual or mass forcible transfers, as well as deportations of protected persons from occupied territory to the territory of the Occupying Power or to that of any other country, occupied or not, are prohibited, regardless of their motive,"10 ${ }^{10}$ should be taken literally — i.e. any such act is illegal, period.

Indeed, the Fourth Geneva Convention is merely an international treaty, and is such it is amendable, but one cannot ignore the fact that 196 countries ratified it at the time of its publication, and that the United States and Israel both joined it later on (in 1955 and 1951, respectively).

To this day, Geneva IV is cited by many members of the international community with respect to the issue of the civilian settlement territories — disputed or otherwise. Moreover, major international bodies, such as the United

\footnotetext{
${ }^{4}$ Kuttab, Daoud (2019). "Pompeo's gift to Netanyahu might bring about new Israeli annexation," Al-Monitor.com

${ }^{5}$ The two-state solution to the Israeli-Palestinian conflict envisages an independent Palestinian state alongside the State of Israel, west of the Jordan River. It is at the core of the 1993 Oslo Accords signed between the parties.

${ }^{6}$ Schelling, Thomas (1966). "Arms and Influence," Yale University Press, pp.25-26

${ }^{7}$ Baker (2019). Ibid., p.3

${ }^{8}$ Geneva Conventions (IV) (1949). "The Protection of Civilian Persons in Time of War," Article 49, the International Committee of the Red Cross

${ }^{9}$ Geneva Conventions (IV) (1949). Commentary of 1958, Article 49: Deportations, Transfers, Evacuations, ibid.

${ }^{10}$ Ibid.
} 
Nations and the International Court of Justice in The Hague, recognize this simplistic interpretation as an acceptable argument.

This chapter presents the history of the treaty, dealing with the settlement of civilians in occupied territory as the basis for interpretation regarding the Jewish settlement enterprise in Judea and Samaria.

Any attempt to delve into the latter demands a short review of the process from which the prohibition on populating an occupied territory was derived and its development over the years.

Article 42 of The Hague Convention of 1907 is considered the widely accepted definition of what amounts to "belligerent occupation" for the purposes of international law: "Territory is considered occupied when it is actually placed under the authority of the hostile army. The occupation extends only to the territory where such authority has been established and can be exercised."11

At the time, this article was ratified by the 44 nations that are signatories to The Hague Convention, and by 1949 it had evolved into Article 49 of the Fourth Geneva Convention, with 196 signatories. In 1998, The Rome Statute of the International Criminal Court - the treaty that established the ICC - lent it further gravitas ${ }^{12}$ by stating that "serious violations of the laws and customs applicable in international armed conflict, within the established framework of international law ... [include] the transfer, directly or indirectly, by the Occupying Power of parts of its own civilian population into the territory it occupies." 13

The basic principles of seizing enemy territory as part of the principles of war unfold simply as early as the early 20th century. ${ }^{14}$ Common wisdom in this respect says that to the victor go the spoils; i.e. it controls the defeated party's land and can do as he pleases with the people. The Fourth Geneva Convention seeks to regulate this issue even at an age when said control could be the result of missile threat and not only occupation per se. ${ }^{15}$

But the issue of the settlements is one of the exceptions to the rule, and hence the next section will examine how the various parties view this issue. Are the settlements "ancestral land" or an "occupied territory"? This definition should be reviewed in light of the situation described in this chapter and the American statement.The statement was ofcourse during the old regime at the USA but the words and the meaning are important to the fight of Israel against the heavy and serious accusations.

\section{The Israeli Settlement Enterprise: Views and Perceptions}

At the end of the 1967 Six-Day War, when Israel seized the Sinai Peninsula from Egypt, the Golan Heights from Syria, and the Judea and Samaria area from Jordan, a new geographic, political, geostrategic, economic, and religious reality was created. ${ }^{16}$

Israel faced a dilemma when, on the one hand, it wanted to continue ruling territories three-times its size prior to the Six-Day War, for both security and economic reasons as well as for reasons of historical and religious affiliation ("ancestral land"). On the other hand, it was clear to every Israeli government that it would meet with international opposition if it attempted to apply Israeli sovereignty over these territories, as was the case when Israel annexed east Jerusalem and the Golan Heights.

In addition, it was clear that having millions of Palestinians suddenly gain Israeli citizenship would create a perilous demographic situation for Israel. ${ }^{17}$ The choice, therefore, was to establish what is briefly defined as "a settlement established by the State of Israel beyond the Green Line as set after the [1967] Six-Day War."18

\footnotetext{
${ }^{11}$ Laws of War (1907): Laws and Customs of War on Land (Hague IV)

${ }^{12}$ Globes Daily (Nov. 24, 2019). "Is the US Declaration on Settlements Contrary to International Law?" online

13 The Rome Statute of the International Criminal Court (1998). Article 8[2] — War crimes, b., viii

${ }^{14}$ Von Clausewitz, Carl (1950). Principles of War, Dover Military History, Weapons, Armor, New York, pp.10-30

${ }^{15}$ Brodie, Bernard (2015). Strategy in the Missile Age, Princeton University Press, pp.54-617

${ }^{16}$ Tal, Israel (1996). National Security: The Israeli Experience, Zmora-Bitan, Tel Aviv, pp.139-147

${ }^{17}$ Ravid, Yisrael (2001), "Israel in the Middle East — The Palestinian Refugees" in Weinberg, David (Editor), Studies in Middle East Security — Publications, Bar Ilan University Press, pp. 375-380

${ }^{18}$ The Green Line is the demarcation line set out in the 1949 Armistice Agreements between the armies of Israel and those of its neighbors Egypt, Jordan, Lebanon, and Syria after the 1948 War of Independence. It is considered as the de facto border between the State of Israel and the Palestinian territories.
} 
From the moment the first settlement of Kfar Etzion ${ }^{19}$ was established in the southern West Bank, a situation was created in which about half a million Israelis are defined as settlers in their ancestral land by some in Israeli society and worldwide, while at the same time, others in Israel and around the world see them as being in violation of international law.

This issue creates a stumbling block for the efforts to resolve the Israeli-Palestinian conflict and is at the heart of a long political and security-oriented debate, in Israel and abroad. In other cases, however, it is presented as a key opportunity or a creative solution to the conflict, such as land swaps between Arab Israeli localities and Israeli settlements, or the two-state solution.

The international approach toward the Israeli settlements has been the subject of endless discussions held in every possible arena. ${ }^{20}$ The United States' position on the matter over the years is one example: Most administrations have maintained ambiguity over the legality of settlements, while some have argued that the settlement enterprise impedes the Israeli-Palestinian peace process.

The only exceptions were President Jimmy Carter, who explicitly stated that the settlements were a violation of international law and effectively allowed the UN to pass three resolutions to that effect between 1979 and 1980; and President Barack Obama, who in 2016 ordered his UN ambassador to refrain from vetoing UN Security Council Resolution 2334, thus allowing the adoption of a resolution labeling the Israeli settlement enterprise in Judea and Samaria a blatant violation of international law.

Most of the references to settlements over the years view them as a clear impediment to peace between Israel and the Palestinians. If we look at a number of historical political events, it is evident that Israel was denounced over its settlement enterprise every step of the way, and that in general, the international community adopted the interpretation of Article 49 in Geneva IV, namely that the Israeli settlements were harming an occupied people — the Palestinians.

As early as 1978, for example, the US State Department, in what would later be called the Hansell Memorandum, ${ }^{21}$ argued that paragraph six of Article 49 "appears to apply by its terms to ... determining the location of the settlements, making land available and financing of settlements, as well as other kinds of assistance and participation in their creation."

In 2004, the International Court of Justice also found the settlements to be illegal under international law: They "violate the Geneva Convention, Article 49."22

In 2016, Resolution 2334 of the UN Security Council condemned "all measures aimed at altering the demographic composition, character and status of the Palestinian Territory occupied since 1967,"23 stating this violated Article 49. And in 2019, the European Union and the Palestinian Authority both declared they see Pompeo's declaration as one "contrary to UN Security Council Resolution 2334."24

A similar reference appears in a November 2019 statement by the Socialist International $^{25}$ as well as in remarks by several Arab and Palestinian officials. For example, Palestinian envoy to the United Kingdom Husam Zomlot claims that Israeli settlements in the West Bank pose "an existential threat" not only to the Palestinians but to the world as a whole, and any support of them could lead to world chaos. ${ }^{26}$ Hani Al-Masri, director general of Masarat, the Palestinian Centre for Policy Research and Strategic Studies in Ramallah, claims that settlements are a trigger for extremists on both sides to incite even more hatred and violence. ${ }^{27}$

\footnotetext{
${ }^{19}$ Kfar Etzion was established between Jerusalem and Hebron in the southern West Bank in 1927, depopulated in 1948 and re-established in 1967.

${ }^{20}$ The Guardian, editorial, 19.11.2019 retrieved from: www.theguardian.com

${ }^{21}$ Letter of the State Department Legal Advisor, Mr. Herbert J. Hansell, Concerning the Legality of Israeli Settlements in the Occupied Territories of April 21, 1978

${ }^{22}$ International Court of Justice (9.7.2004). "Legal Consequences of the Construction of a Wall in the Occupied Palestinian Territory," pp. 171-172.

${ }^{23}$ UN Security Council Resolution 2334

${ }^{24}$ Globes (27.11.2019). "Is the US declaration about the legality of the settlements contrary to international law?"

${ }^{25}$ Socialist International (20.11.2019) "US Declaration Is an obstacle to peace"

${ }^{26}$ Kuttab D., Ibid.

${ }^{27}$ Ibid.
} 
On the other hand, there have been a handful of references that considered the settlements a legal enterprise even before the Pompeo's declaration, citing several key reasons.

First, some view the area in question as not being under occupation, which would therefore mean the Fourth Geneva Convention does not apply to it, as stated by Israeli Supreme Court Justice Edmund Levy. ${ }^{28}$

Another reason is that the territories were not under Jordanian control before the 1967 Six-Day War but rather were territories that should have been under Israeli control in 1948, and therefore they are not occupied land.

A third reason cites the historical-religious rationale by which Judea and Samaria are ancestral land that has been liberated.

Other examples, as cited by Baker, ${ }^{29}$ include jurist Eugene Rostow, ${ }^{30}$ who argued that the Fourth Geneva Convention "intended to prevent a practice adopted during the Second World War by certain Powers, which transferred portions of their own population to occupied territory for political and racial reasons or in order, as they claimed, to colonize those territories. Such transfers worsened the economic situation of the native population and endangered their separate existence as a race. ... There is no doubt that Jewish settlers in the West Bank are volunteers who have not been forcibly transferred by their government and their transfer has had no adverse effects."

Civil rights attorney Ambassador Morris B. Abram, one of the authors of Geneva IV, also claimed that the treaty was "not designed to include situations like the Jewish settlement in the territories." ${ }^{31}$

Still it is the side that sees the settlement enterprise as illegal that is more dominant. This is apparent in British journalist Barbara Plett's November 19, 2019 article, in which she openly blames Israel for impeding the peace process by persisting in its support of the settlement enterprise. ${ }^{32}$

She further argues that US support for the legal validity of the settlements will spur future violations of international law, and that the very existence of the settlement enterprise undermines the feasibility of the two-state solution, dealing the notion of Palestinian statehood a crippling blow while benefiting Israel.

Plett and many others believe Israel's so-called "unfair" advantage will manifest in the form of annexing the territories on which the settlements are built, predominately the Jordan Valley area. This, in turn, will allow Israel to cement an eastern border with Jordan and vis-à-vis any future Palestinian state based on existing settlements in the Jordan Velley.

But what does all of this mean for the future of the Judea and Samaria settlement enterprise, especially in light of Pompeo's declaration? -did the change of the regime at the USA and the Hague court and is decisions will change the atmosphere in the middle east and will change the attitude towards Israel? -what was so special about the Pompeo declaration and does it have an influence today?

\section{The Pompeo Declaration: Possible Motives}

On November 18, 2019, US Secretary of State Mike Pompeo announced a change in US perception of the legal validity of Israeli settlements in Judea and Samaria, and stressed the move was a reversal by the Trump administration of the previous administration's policy on the issue. ${ }^{33}$

Furthermore, Pompeo stressed that he was aware that his statement seemingly diverted from international law, but he made it clear that he was referring exclusively to settlements and not setting a precedent for similar cases around the world. ${ }^{34}$

While the very declaration and the very reservation expressed with respect to international law demonstrate that he was aware of previous reservations to the effect, Pompeo still exclaimed: "The establishment of Israeli civilian settlements in the West Bank is not per se inconsistent with international law."135

\footnotetext{
${ }^{28}$ Justice (ret.) Edmund Levy, (2012). Report on the Legal Status of Building in Judea and Samaria, p.13

29 Baker, ibid.

${ }^{30}$ Eugene Victor Debs Rostow was an American legal scholar her served as dean of Yale Law School and as undersecretary of state for Political Affairs under President Lyndon B. Johnson.

${ }^{31}$ Baker, ibid.

${ }^{32}$ Plett Usher, Barbara (19.11.2019). US settlement move reduces chances of Israeli-Palestinian peace deal, BBC News

${ }^{33}$ Jonathan Ofir (19.11.2019). "Pompeo declaration should be a wakeup call to liberal Zionists," Mondoweiss.net

${ }^{34}$ Collins, Liat (22.11.2019). "My word: Diplomatic declarations and facts on the ground," Jerusalem Post

${ }^{35}$ Secretary Pompeo's Comments on Israeli Civilian Settlement Activity, US Embassy in Israel
} 
Three remarks Pompeo included in his statement seemed to reinforce scholars' and publicists' suggestions regarding the motives driving it. ${ }^{36}$

The first note sees the Israeli judiciary as the one that will decide on the issue of settlements rather than international law. The second evokes the need to hold negotiations in light of the factual and historical realities surrounding the settlement enterprise. And the third negates a legal solution based on legal justice, underscoring that this is a political issue rather than an ethical or moral one, and therefore only negotiations can resolve it.

Pompeo's remarks raise the issue of the timing of the declaration and highlight the need to delve into its motives even further, especially when considering that it came against the backdrop of President Trump's recognition of Jerusalem as Israel's capital. $^{37}$

Furthermore, a week prior to Pompeo's statement, the European Court of Justice ordered the bloc's 28 member-states to label Israeli goods made in Judea and Samaria settlements. ${ }^{38}$ The statement was also made at a time when the US was officially embarking on the 2020 presidential election campaign, launched against the backdrop of impeachment proceedings against President Trump, who has since been acquitted in the Senate. To understand the conditions today we must understand the reasons and the background to the Pompeo declaration.

During this time, Israel also called an unprecedented third general election in the span of one year, and the political stalemate has crippled it on a diplomatic, budgetary, and social level. In the interim, tensions between Iran and the US have exacerbated, ${ }^{39}$ and most recently, the Trump administration released its so-called "deal of the century ${ }^{40 "}$ for the Israeli-Palestinian peace process.

Against this backdrop and on the basis of the Pompeo declaration on the one hand, and the known international legal objections to it on the other, there are a number of explanations that validate the timing with which the US's top diplomat made his statement. We have to understand his aims and meanings to learn what affected the International court of law when it decides to investigate Israel about crime of war and especially about the Jewish settlements. Of course, all of this under the warning to the readers that the Pompeo declaration was 3 years ago but still we have so much to learn from it.

The first relates to the "deal of the century." Just as the declaration of Jerusalem as the Israeli capital, and the release of the Middle East peace plan, so too does this statement reflect an American effort to lay the groundwork for major and painful concessions on both sides in order to propel and eventually finalize the Israeli-Palestinian peace process: not on the basis of international courts or treaties but on the basis of actual give-and-take negotiations - just like they do in business, as the US President prefers. Today the new American regime sees the deals very differently and it affects every decision around the globe regarding this argument including the court decision.

The second explanation relates to the first but underscores the Americans' "contrarian" position to the rulings rendered by The Hague. The mandatory labeling of settlement goods is a move that has reminded many Americans of the dark days of the Nazi regime, and it is highly likely to have played a part in Washington's decision to declare the change in its policy toward the Israeli settlement enterprise when it did. Today the situation is still the same and if the Bidden regime will continue to oppose the spirit of the Hauge court Israel will still gain support from the USA. Today the attitude towards the court change to the other direction.

The third explanation relates to Israeli politics. Trump and his people understood that Israeli Prime Minister Netanyahu, who is facing indictments in three corruption cases, is in something of a political pickle and that any help they may lend him could provide him with the political capital he needs to get re-elected. It was important before the elections and very important after the draw at the March elections.

This shift in policy by the US bolsters Netanyahu's positions, as well as the administration's ties with him, and all under the understanding Trump and his people face their own challenges in the 2020 presidential elections.

The fourth explanation is Trump's need to appeal to the Jewish vote, as evident from the fact that on the heels of the

\footnotetext{
${ }^{36}$ O'Reilly, Andrew (18.11.2019). "Trump administration eases US stance toward Israeli settlements in West Bank," Fox News

${ }^{37}$ Shavit Baruch Pnina, Hatuel Radoshitsky, Michal (2019). "Legal or Illegal? The Pompeo Declaration on Settlements and its Implications," in Overview Vol. 1230, Institute for National Security Studies, Tel Aviv University

${ }^{38}$ Israel Hayom (13.11.2019). "EU court rules goods from Israeli settlements must be labeled"

39 Ettinger, Yoram (21.11.2019) "Israel in Judea and Samaria (West Bank) advances US interest," the Ettinger Report

${ }^{40}$ White House Staff (2020). "Peace to Prosperity," The White House
} 
Pompeo declaration, the president issued an executive order targeting anti-Semitic and anti-Israel speech, which in some ways is a clear play for the Jewish vote, which traditionally splits $70 \%$ to $30 \%$ in favor of the Democrats.

The executive order places American Jews in a position where they need to sway the vote in favor of the Republicans and Trump, who has already been referred to as "first Jewish president." ${ }^{41}$ This refers to any American president today and in the future.

This reason is further cemented by the fifth explanation, or how the declaration's timing has to do with Trump's need to cater to the evangelical electorate. The evangelicals are staunch supporters of Trump and see Jerusalem as the eternal capital of Israel and Judaism as the ultimate religion, and they are a political forced to be reckoned with in the US, as they number 30 million people.

This section of the voter base is very important to Trump, and he knows increasing American support for Israel will bring evangelicals in droves to the polls come the presidential elections in November.

The sixth explanation stems from the fact that Israel is a valuable strategic asset for the United States. For the US, Israel is in many ways a form of a huge, static, fortified, powerful, and formidable aircraft carrier against Iran and its allies, and strategically against Russia and its allies.

The understanding that Israel supports Jordan — despite the apparent friction between them and vis-à-vis the Muslim world - the stable Israel-Egypt peace treaty, and the slowly warming ties with Saudi Arabia, effectively create a substantial base for the Americans should US troops need to be deployed on the ground to counter any threat facing the US in the Middle East, from Turkey and Iran to Russia.

The American understanding that a strong Israel is vital to protect their own interests in the region reinforces every step they take (such as the Pompeo declaration) to cement the bond and reciprocity between the two nations. Pompeo's declaration and the policy shift outlined in the US Middle East peace plan, which effectively allow Israel to annex territories in the Jordan Valley and Judea and Samaria is the type of action that will underpin the symbiotic connection between the US and Israel.

\section{Summary}

To summarize this essay, the main implication of the Hague court decision about Israel is the opposite of Pompeo declaration and it raises questions as to how it may be translated on the ground. This declaration facing the Hauge court decisions show the world how complicated and political is the atmosphere in the middle east. Undoubtedly, at first the statement will be perceived as an obstacle to the Israeli-Palestinian peace process, and it is also clear that the United States will be perceived as an unfair mediator between the parties, who is biased in favor of Israel. This, of course, will naturally jeopardize the chances of any future peace deal from materializing.

Another point to consider on this issue is what happened after Trump and the Republicans lose the 2020 presidential elections, and the Democrats come to power. A Democratic administration could potentially renege on the pledges made by its predecessor, and this may pose an actual risk for Israel, should it come to pass.

And then there is the Palestinian reaction. Palestinian Authority President Mahmoud Abbas has already rejected the US peace plan, saying it added insult to the injury of the Pompeo declaration. The militant Palestinian factions have already called for the resumption of an armed struggle, and as Abbas has already appeared before the United Nations Security Council to protest and reject the peace plan, it stands to reason the Palestinians, who perceive the settlement enterprise as a "war crime," will also pursue action against Israel in The Hague.

Another aspect that must be taken into consideration is the divergence between Israel and the American Jewish community, and the growing polarization within the American Jewish community. These rifts may grow now that issues that had always been gingerly skirted and left intentionally vague have been placed on the negotiating table in full.

The need to finally deal with hot-button issues, such as the annexation of the Jordan Valley or the future of the Judea and Samaria settlement enterprise, may cause the proverbial explosion in intra-community relations among US Jewry and between them and the Israeli government.

Against these points, the American understanding that the Israeli-Palestinian conflict and the various issues deriving from it are political and diplomatic in nature — and not legal — becomes far more poignant. In turn, this may affect the global perception of the matter, especially with respect to the Europeans.

No convention, treaty, or legal decree will facilitate true peace or justice to the parties fighting over this small piece of land in the Middle East - only direct and resolute diplomatic negotiations can resolve the regional conflict.

${ }^{41}$ Concha, Joe (12.12.2019). "Mark Levin calls Trump 'first Jewish president," The Hill 
This is the primary objective of Pompeo's declaration: to push Israel and the Palestinians to resume the peace talks, stalled since 2014, and to make them realize that no treaty or international court can take the place of direct negotiations. And this must be the goal and target of ye Hauge court of law.

The issue of Israeli settlements is a key point in any future peace deal, which is why the Palestinians are trying to undermine their legal status - it allows them to continue dodging direct negotiations with Israel.

To conclude, the policy shift outlined in the Pompeo declaration and not the Hauge decision seeks to prod the parties to resume negotiations, and therefore it does not infringe on international law or undermine the tenets of the Fourth Geneva Convention. On the contrary - it bolsters them while urging the parties to reach an agreement that could lead to a dramatic change in the map of regional and global interests.

\section{Notes}

1. The two-state solution to the Israeli-Palestinian conflict envisages an independent Palestinian state alongside the State of Israel, west of the Jordan River. It is at the core of the 1993 Oslo Accords signed between the parties.

2. The Green Line is the demarcation line set out in the 1949 Armistice Agreements between the armies of Israel and those of its neighbors Egypt, Jordan, Lebanon, and Syria after the 1948 War of Independence. It is considered as the de facto border between the State of Israel and the Palestinian territories.

3. Kfar Etzion was established between Jerusalem and Hebron in the southern West Bank in 1927, depopulated in 1948 and re-established in 1967.

\section{References}

Baker, A. (2019). The Legality of Israel's Settlements: Flaws in the Carter-Era Hansell Memorandum. Jerusalem Center for Public Affairs. Retrieved from https://jcpa.org/article/the-legality-of-israels-settlements

Barclay, F. (2017). Settler colonialism and French Algeria. Settler Colonial Studies, 8(2), 115-130. https://doi.org/10.1080/2201473X.2016.1273862

Brodie, B. (2015). Strategy in the Missile Age. Princeton University Press, pp.54-617.

Collins, L. (2019). My word: Diplomatic declarations and facts on the ground. Jerusalem Post. Retrieved from https://www.jpost.com/Israel-News/My-word-Diplomatic-declarations-and-facts-on-the-ground-608656

Concha, J. (2019). Mark Levin calls Trump 'first Jewish president. The Hill. Retrieved from https://thehill.com/homenews/media/474260-mark-levin-calls-trump-first-jewish-president

Ettinger, Y. (21.11.2019). Israel in Judea and Samaria (West Bank) advances US interest. The Ettinger Report. Retrieved from https://theettingerreport.com/israel-in-judea-and-samaria-west-bank-advances-us-interest

Geneva Conventions (IV). (1949). Commentary of 1958, Article 49: Deportations, Transfers, Evacuations. The International Committee of the Red Cross. Retrieved from https://ihl-databases.icrc.org/ihl/COM/380-600056?OpenDocument

Geneva Conventions (IV). (1949). The Protection of Civilian Persons in Time of War. Article 49, the International Committee of the Red Cross. Retrieved from https://ihldatabases.icrc.org/applic/ihl/ihl.nsf/Treaty.xsp?ction=openDocument\&documentId=AE2D398352C5B02 8C12563CD002D6B5C

Globes. (2019). Is the US declaration about the legality of the settlements contrary to international law? Globes. Retrieved from http://www.globes.co.il/serve/globes/printwindow.asp?did=1001308161

International Court of Justice. (2004). "Legal Consequences of the Construction of a Wall in the Occupied Palestinian Territory," pp. 171-172. Retrieved from https://www.icj-cij.org/files/case-related/131/131-20040709-ADV-01-00-EN.pdf

Jonathan, O. (2019). Pompeo declaration should be a wakeup call to liberal Zionists. Mondoweiss. Retrieved from https://mondoweiss.net/2019/11/pompeo-declaration-should-be-a-wake-up-call-to-liberal-zionists/

Justice (ret.) Edmund Levy, (2012). Report on the Legal Status of Building in Judea and Samaria. pp.13. The Prime Minister's Office. Retrieved from http://www.pmo.gov.il/Documents/doch090712.pdf

Kuttab, D. (2019). Pompeo's gift to Netanyahu might bring about new Israeli annexation. Al-Monitor. Retrieved from www.al -monitor.com/pulse/original/2019/11/us-Israel

Laws of War. (1907). Laws and Customs of War on Land. Hague IV. Retrieved from 
https://avalon.law.yale.edu/20th_century/hague04.asp

Letter of the State Department Legal Advisor, Mr. Herbert J. Hansell, Concerning the Legality of Israeli Settlements in the Occupied Territories (1978). The US State Department. Retrieved from https://www.hlrn.org/img/documents/USSDLegalAdvisorHansell_ltr.pdf

Morgenthau, H. J. (1948). Politics Among Nations: The Struggle for Power and Peace, New York, Alfred A. Knopf, pp.50

News agencies, Israel Hayom staff (2019) "EU court rules goods from Israeli settlements must be labeled." Israel Hayom. Retrieved from https://www.israelhayom.com/2019/11/13/eu-court-rules-goods-from-israeli-settlements-must-be-labeled/

O'Reilly, A. (2019). Trump administration eases US stance toward Israeli settlements in West Bank. Fox News. Retrieved from

https://www.foxnews.com/politics/pompeo-expected-to-announce-softening-on-us-stance-towards-israeli-settleme nts

Plett, U. B. (2019). US settlement move reduces chances of Israeli-Palestinian peace deal. BBC News. Retrieved from https://www.bbc.com/news/world-middle-east-50481519

Ravid, Y. (2001). Israel in the Middle East - The Palestinian Refugees. In Weinberg, David (Ed.), Studies in Middle East Security - Publications, Bar Ilan University Press, pp. 375-380.

Schelling, T. (1966). Arms and Influence, Yale University Press, pp.25-26.

Secretary Pompeo Comments on Israeli Civilian Settlement Activity, US Embassy in Israel. Retrieved from https://il.usembassy.gov/secretary-pompeo-comments-on-israeli-civilian-settlement-activity/

Shavit, B. P., \& Hatuel, R. M. (2019). Legal or Illegal? The Pompeo Declaration on Settlements and its Implications. Overview, 1230. Institute for National Security Studies, Tel Aviv University. Retrieved from https://www.inss.org.il/he/publication/are-they-legal-or-not-pompeos-announcement-on-the-israeli-settlements/

Socialist International, press release (2019). US Declaration Is an obstacle to peace. Socialist International. Retrieved from

https://www.socialistinternational.org/news/press-releases/us-declaration-on-israeli-settlements-an-obstacle-to-pea ce-863/ Tal, Israel (1996). National Security: The Israeli Experience, Zmora-Bitan, Tel Aviv, pp.139-147

The Guardian (editorial). (2019). View on Israeli settlements: still illegal. The Guardian. Retrieved from https://www.theguardian.com/commentisfree/2019/nov/19/the-guardian-view-on-israeli-settlements-still-illegal

The Rome Statute of the International Criminal Court, 1998, Article 8[2] - War crimes, b., viii, International Criminal Court. Retrieved from: https://www.icc-cpi.int/resourcelibrary/official-journal/rome-statute.aspx\#top

UN Security Council Resolution 2334 (2016). Retrieved from https://www.un.org/webcast/pdfs/SRES2334-2016.pdf

Von Clausewitz, C. (1950). Principles of War. Dover Military History, Weapons, Armor, New York, pp.10-30

White House Staff. (2020). Peace to Prosperity (Report). The White House. Retrieved from https://upload.wikimedia.org/wikipedia/commons/a/a6/Peace_to_Prosperity.pdf

\section{Copyrights}

Copyright for this article is retained by the author(s), with first publication rights granted to the journal.

This is an open-access article distributed under the terms and conditions of the Creative Commons Attribution license which permits unrestricted use, distribution, and reproduction in any medium, provided the original work is properly cited. 